INTERNATIONAL JOURNAL OF MULTIDisciplinARY RESEARCH AND ANALYSis

ISSN(print): 2643-9840, ISSN(online): 2643-9875

Volume 04 Issue 04 April 2021

DOI: 10.47191/ijmra/v4-i4-02, Impact Factor: 6.072

Page No.- 368-371

\title{
Opportunities and Prospects for the Development of Ecotourism in the Jizzakh Oasis
}

\author{
Khakima Davlatova ${ }^{1}$, Ozodbek Nematov ${ }^{2}$ \\ ${ }^{1}$ Master Student, Jizzakh State Pedagogical Institute, Jizzakh region, Uzbekistan \\ ${ }^{2} 4$ th Year Student, Faculty Of History National University Of Uzbekistan Named After Mirzo Ulugbek, Uzbekistan
}

ABSTRACT: This article reflects the ecotourism opportunities of Jizzakh region. In particular, information was provided on the tourist potential of Zaamin Bakhmal and Forish regions.

KEYWORDS: Ecotourism, activism, home hotels, ecotourism facilities, infrastructure, oasis ecotourism facilities, tour operator, relief, GEF projects, speleotourism

\section{INTRODUCTION}

In recent years, a number of measures have been taken in our country to preserve Mother Nature and preserve biological species. In 2001-2005, Uzbekistan implemented the GEF International Bank for the Conservation of Biological Diversity of the Western Tien Shan and the international project Europe Aid. These projects are directly related to environmental protection and attracting local people to tourism.

\section{THE MAIN RESULTS AND FINDINGS}

As an alternative activity, the local community is invited to receive and serve foreign and local tourists interested in tourism, i.e. local flora and fauna, landscape, folk history and culture. Even if the industry is seasonal, with a clear plan and success, it is possible to extend the season and earn the same amount throughout the year. Provides accommodation, meals, transportation, customs and crafts demonstrations, guidance, protection and security services.

The development of this industry will encourage local crafts based on national traditions and the mentality of our people: the population will restore handicrafts and hunting to the best of their ability. It will be an additional source of income that does not require a large investment. In addition, the local population provides tourists with quality food products grown not only from other regions, but also from subsistence farming (vegetables grown on vacant lands in the residential area). Begins.

As a result, the population itself begins to actively protect nature, because if the environment deteriorates, foreign tourists will not come, which will have a negative impact on the income of the local population. As a result, stakeholders will have to allocate part of their funds for conservation activities and the restoration of cultural and artistic monuments.

Importantly, the development of this sector will stimulate communications, new technologies, the construction of roads, communication lines, medicine, drinking water, energy and other activities.

The Western Tien Shan is the territory of the three states of Uzbekistan, Kazakhstan and Kyrgyzstan. Therefore, it is impossible to develop tourism here without active cooperation and coordination between these countries. The issue is not only the creation of cross-border tourist routes, which are popular with foreign travelers, but also the preservation of natural resources, prevention of savage extinction of animals through poaching, reducing the negative impact of industry, boosting the local economy. also. Both the government and the local community should be interested in the development of the region. They have to control all the economic processes that take place in their area and take control of the management. The TACIS project to conserve the natural resources of the Western Tien Shan is aimed at solving this problem.

Currently, ecotourism products are in great demand among foreign and domestic tourists. According to experts, Central Asia could become a unique "Mecca" for nature travelers. In this regard, on April 17, 2006 the Resolution of the President of the Republic of Uzbekistan No. PP-325 "On measures to accelerate the development of the service sector of the Republic of Uzbekistan 2006-2010" was adopted. In order to implement this decision and develop ecotourism, the State Committee for 


\section{Opportunities and Prospects for the Development of Ecotourism in the Jizzakh Oasis}

Nature Protection has developed a "Concept for the development of ecotourism in the Republic of Uzbekistan and its near future."

This concept envisages the necessary conditions, organizational and legal issues for the gradual development of ecotourism in our country. If these issues are addressed, the Republic of Uzbekistan will have a great opportunity to become one of the most developed countries in the world in the field of ecotourism.

Despite the great potential of tourism in Uzbekistan, its share in GDP is only $0.5 \%$. Although the industry employs a total of about 6,000 people, there are at least 30,000 additional jobs that will serve tourists. In addition, other sectors that supply goods and provide various services to replace hospitality - energy, utilities, road services, public safety, medicine, insurance, banking, foreign policy, and connections, etc. (more than 20 sectors of the economy). However, the peculiarity of tourism is that, although it is possible to assess the level and quality of service, the "effects" that can not be measured by any measure impression, spiritual nourishment, satisfaction, aesthetic pleasures, etc. can be enumerated.

According to official data, in 2006 the import of tourist services amounted to 21.2 US dollars per 1 US dollar, in 2007 the ratio was 1: 23.8 US dollars, an increase of $112 \%$. swelling was observed. However, the figures show that exports of services accounted for $14.7 \%$, imports for $24 \%$ and the negative balance for $14.3 \%$.

It is known that no factor in the world is static, there are changes that lead to an improvement or deterioration of the situation in the country. In other words, tourists respond to changes in the situation with their "feet": if they do not like something, they change their route. In world practice, the volume of annual travel of national and foreign citizens across the country is considered to be domestic tourism. However, it is often difficult to determine the number of tourists who are citizens of this country, because during the trip they do not perform formalities (registration), do not always stay in hotels, boarding houses and holiday homes, their visits are for other purposes (shopping). to do, to visit relatives, to go to weddings). Such trips make up the bulk of domestic travel. Such trips are usually more intense in late spring, early summer, and fall. Such travelers prefer cheaper rail and road transport.

At the same time, it should be noted that the share of foreigners in the total volume of domestic tourism is $50.7 \%$, the largest number of foreign visitors is in Tashkent (50.1\%), Bukhara region (19.1\%), Samarkand region (15.4\%), Khorezm (8.94\%) and Surkhandarya (3.88\%) regions. Thus, $94.8 \%$ of tourists visiting Navoi region are citizens of other countries. In Bukhara region it is $73.9 \%$, in Samarkand region - 51.7\%, in Surkhandarya region - 84.2\%, in Khorezm region - 50.1\%.

Thus, the statistics allow us to draw the following conclusions: First, the internationally reputable and well-advertised routes (Tashkent-Samarkand-Bukhara-Khiva) have been operating for many years and have accumulated extensive experience. .In 2008 , they accounted for the bulk of all foreign visitors (92\%).

Secondly, foreign tourists come to Termez, Karshi and Navoi for special purposes (archeology, ethnography, natural landscapes). But tourism products in this area are not popular.

Third, some areas, such as the Fergana Valley, Syrdarya, and Jizzakh, remain transit routes because more money is needed to popularize them. In addition, tour operators recommend them not for public consumption, but for individual orders (hunting, astronomy, ecology, folklore).

There are more than 7,000 historical, cultural, architectural and archeological sites in Uzbekistan. That's what attracts foreigners like a melody. According to B. Turaev, “... 545 of them are architectural, 575 historical, 1457 art monuments, more than 5500 objects are of archeological value. However, only 140 of them are involved in the tourist demand. Of the facilities listed above, more than 200 are under repair, with 500 under repair; that's tens of millions of dollars a year. The experience of other countries shows that for many tourists, the process of repair itself is interesting. In this regard, there are several thousand archeological sites in Uzbekistan. In addition, there are more than 300 museums and 1,200 folk art enterprises in the country. The number of tourist attractions is 144 in Tashkent, 118 in Samarkand, 221 in Bukhara and 310 in Khiva. However, in general, tourism authority is underused."

After the independence of the Republic of Uzbekistan, radical reforms are being carried out in all sectors of the economy. In particular, the state pays great attention to the development of tourism. In his works and practical activities, President of the Republic of Uzbekistan Islam Karimov emphasizes that it has always been a dream of tourists around the world to see the rich historical heritage, monuments, tombs and historical monuments built by our great ancestors, as well as the land where they lived. Also, the so-called paradise of Uzbekistan creates favorable conditions for our compatriots and foreign tourists who want to enjoy the diverse flora, fauna and charming nature in all four seasons of the year.

Zaamin district fascinates not only with its natural scenery, clear waters, fresh air-saturated airy landscapes of the Turkestan mountain range, but also with the fact that it is the second settlement of the ancient country of Ustroshona and the scholars who lived on this land. To create a history of each place on the routes set by the administration of Zaamin district and a group of activists in order to please our leaders and foreign tourists with the wonders of nature, along with the wonders of nature, our 


\section{Opportunities and Prospects for the Development of Ecotourism in the Jizzakh Oasis}

great heritage and our efforts for development today. , beautification, creation of conditions in accordance with world standards.

Jointly approved by the Resolution of the Cabinet of Ministers of the Republic of Uzbekistan dated March 9, 201240 "On measures to attract non-discriminatory technical assistance (grants) from international financial and economic institutions, donor countries to the Republic of Uzbekistan in 2010" If we pay attention to the results of the analysis carried out in the framework of the project of the United Nations "Support to local government, civic participation and cooperation", we draw your attention to the following conclusions about the tourist opportunities in the district.

So, the strengths of tourism development in the strong Jizzakh region:

1. Ecologically clean and very close to nature is one of the most important issues today.

2. It has healing properties for the human body

3. Existence of the National biological national park which is well studied from biological, ecological, historical and cultural point of view

4. Presence of unique natural, historical and cultural tourist sites in the territory of the People's Park and Zaamin State Reserve.

5. Support of tourism by local and regional leaders. The population has confidence in the future of tourism.

Also as weaknesses:

1. Lack of highly qualified personnel.

2. Insufficient number of managers working in the field of tourism

3. The activity of receiving tourists is still weak, due to the lack of basic resources of the local population, as well as their lack of knowledge and skills in the field of tourism.

4. Lack of qualified staff in the reception and service of tourists among the staff of the national park, as well as poor organization of work in this area.

5. It turns out that there is no mechanism for interaction and support between the local population and the staff of the national park, as well as tourism development agencies.

However, it is noted that there are many opportunities for the establishment and further development of tourism in the natural areas of Jizzakh region.

1. Possibility to form an organization responsible for the formation of infrastructure, taking full responsibility.

2. The formation of a body that approaches tourism from a professional point of view.

3. Availability of hospitality and high quality services to visitors.

4. Cooperation of the local population with the management and tourism officials.

5. The fact that the local population and the staff of the national park have at least a little knowledge and skills in the field of tourist services, and efforts are being made to fully explore.

It is also noted that there are some risks. For example,

1. So far there are no clear tourist routes and the existing ones are rarely advertised.

2. Decreased payment of state fees in the field of tourism and the lack of attention of local entrepreneurs in this area, despite the availability of other opportunities.

3. The climate of the region is strongly dependent on natural changes.

4. Failure of the staff of the specially protected area in the area to take full responsibility for the management of visitors in the field of tourism. As a result, due to the lack of aesthetic and ecological literacy of tourists and visitors, there is a high level of environmental pollution, life-threatening situations (fires, water pollution, waste, etc.).

5. There are restrictions on the development of domestic and foreign tourism, indicating a lack of knowledge and skills, a onesided approach to tourism, inadequate actions in the organization of souvenirs, folklore and other entertainment activities, wishes.

\section{CONCLUSION}

Today, along with all sectors of tourism in the world, there is a growing demand for trips to natural sites and villages. In other words, the types of culture, history and nature study make up $15-23 \%$ of the total tourism. Ecotourism occupies $10 \%$ of the market compared to some other tourism markets. Its growth rate in the tourism industry has increased by 2-3 times. In developed countries, nature travel is one of the most expensive forms of recreation and study, but thousands of people do not spare their money for it. 


\section{REFERENCES}

1) Nematov, O., Kushbakova, M., \& Ruzimurodova, Z. (2020). SOME OF THE WORK WITH UNORGANIZED YOUTH IN THE NEIGHBORHOOD. Студенческий вестник, (11,3), 82-85.

2) Tolipov F.S. Community traditions in the form of family life of the people of Nurata oasis.Tashkent:, 2006.

3) Nematov, O. (2018). Historical and religious monument of muhammad sharif (Mevlanagrekushoh). Asian Journal of Multidimensional Research (AJMR), 7(9), 448-452.

4) Hakimov Q.M. “Forish Tajiks: Territorial location and some ethnographic features".- Scientific bulletin. Tashkent: 2020, №5

5) Оға Бургутли. Жиззах вилояти зиёратгохлари. Т.: Фан. 2008. Б.9).

6) Ne'matov.O. Asian Journal of Multidimensional Research ( AJMR ) ( Double Blind Refereed \& Reviewed International Journal) Vol 7, Issue 9, September 2018, Historical and religious monument of Muhammad Sharif

7) Kholikulov, A., \& Nematov, O. N. (2020). The Role Of The Principalities Of The Kashkadarya Oasis In The Political History Of The Bukhara Emirate In The XIX-Early XX Centuries. The American Journal of Social Science and Education Innovations, 2(11), 79-85.

8) Davlatova, K. (2021). Forish Tajiks: Territorial Location And Traditions. The American Journal of Social Science and Education Innovations, 3(03), 338-343.

9) Mirkomil, G., Lapasova, U., \& Umurzakova, G. (2020). Territorial Aspects Of The Organization Of Ecotourism Routes In The Turkestan Ridge. The American Journal of Interdisciplinary Innovations and Research, 2(11), 87-90.

10) Khudoyberdiyevich, D. A., \& Rakhmonkulovich, N. K. (2018). The contribution of sarah sviri to the study of the scientific heritage of hakim tirmidhi. ACADEMICIA: An International Multidisciplinary Research Journal, 8(11), 60-67.

11) Хайдаров, И. М., \& Каримов, Н. Р. (2017). CLASSIFICATION OF THE SCIENTIFIC HERITAGE OF HAKIM TIRMIDHI. In EUROPEAN RESEARCH (pp. 28-31). 